\title{
A note on the susceptibility of $N$. gonorrhoeae to contraceptive agent Nonyl-P
}

\author{
M. E. COWAN* AND G. EWART CREE† \\ From the Departments of Bacteriology and Venereal Deseases, Lister Hospital, Stevenage, Herts
}

The problem of venereal disease control-particularly that of gonorrhoea, has been widely discussed (Catterall, 1970; King, 1970). Epidemiological control, with case finding, treatment of contacts, cluster testing, prophylactic treatment, and so on, appear to have limited impact. To quote Webster (1970): 'A sound epidemiological principle is that no infectious disease is ever controlled by treating cases alone'. A vaccine, although not yet practical, may well encounter public resistance.

The advent of the oral contraceptive pill and the loop (IUD) have reduced the use of the condom as a contraceptive. The preferable combination from the public health point of view would be a contraceptive for local use in women which had both spermicidal and anti-infectious properties (Guthe, 1972). Preliminary studies with this goal in view have been reported by Arnold and Cutler (1970), who suggested a combined prophylactic-contraceptive against syphilis.

The effect of various contraceptive agents in vitro has been examined by Singh, Cutler, and Utidjian (1972). One of them was Delfen Cream-containing 5 per cent. nonyl phenoxyl polyethoxy ethanol (Nonyl-P). This compound has long been used as a contraceptive agent in the United Kingdom. Its contraceptive qualities as a 5 per cent. cream have been reported (Rovinsky, 1964; Behne, Clarke, Jennings, Pallais, Olsen, Wolf, and Tyler, 1956). The side-effects were minimal; 4.9 per cent. complained of burning or irritation. Using a $1.75 \mathrm{ml}$. pessary of 5 per cent. Nonyl-P in a stearate base, the final concentration in the vagina is estimated to be a minimum of 0.8 per cent., assuming dilution with $5 \mathrm{ml}$. each of average ejaculate and vaginal fluid (Hotchkiss, 1945).

\section{Method and Results}

20 per cent. $w / v$ stock solution of Nonyl-P was prepared in glass-distilled water. Serial dilutions were made in nutrient broth (Oxoid No. 2). $1 \mathrm{ml}$. from each dilution was added to previously prepared 5 per cent. heated horse

Received for publication July 7, 1972

*Chief Technician, Department of Bacteriology

†Consultant Venereologist blood agar (Oxoid Diagnostic Sensitivity Test Agar Base) cooled to $56^{\circ} \mathrm{C}$. Each agar-Nonyl-P dilution was mixed thoroughly and poured into a Petri dish. The agar was dried and when set inoculated with $N$. gonorrhoeae (NCTC 3375). To produce confluent growth it was incubated in a candle-extinction jar at $37^{\circ} \mathrm{C}$. for 48 hours.

The highest dilution of Nonyl-P to produce complete inhibition of the organisms was taken as the minimum inhibitory concentration (MIC). This was found to be 0.6 per cent. A scanty growth of $N$. gonorrhoeae was obtained in the presence of 0.4 per cent. Nonyl-P, whereas 0.2 per cent. produced no inhibition (Table I).

TABLE I Inhibition of $\mathrm{N}$. gonorrhoeae by Nonyl-P

\begin{tabular}{|c|c|}
\hline $\begin{array}{l}\text { Concentration of Nonyl-P } \\
\text { (per cent.) }\end{array}$ & Grozvth of N. gonorrhoeae \\
\hline Positive control (without Nonyl-P) & Growth + + \\
\hline $\begin{array}{l}1 \\
0 \cdot 8 \\
0 \cdot 6 \\
0 \cdot 4 \\
0 \cdot 2 \\
0 \cdot 1 \\
0 \cdot 08 \\
0 \cdot 06 \\
0 \cdot 04 \\
0 \cdot 02\end{array}$ & $\begin{array}{l}\text { No growth } \\
\text { No growth } \\
\text { No growth } \\
\text { Scanty growth }+ \\
\text { Growth + + } \\
\text { Growth + + } \\
\text { Growth + + } \\
\text { Growth + + } \\
\text { Growth + + } \\
\text { Growth + + }\end{array}$ \\
\hline
\end{tabular}

The speed of action was investigated with a suspension of N. gonorrhoeae (NCTC 3375), prepared by washing colonies grown on heated blood agar plates and suspending them in nutrient broth to give a concentrate of approximately $10^{6}$ organisms per $\mathrm{ml} .5 \mathrm{ml}$. of this suspension was added to an equal volume of 1.2 per cent. Nonyl-P (final concentration of $0.6 \mathrm{per}$ cent.) and incubated at $37^{\circ} \mathrm{C}$. A control dilution without Nonyl-P was incubated at the same temperature.

$0 \cdot 1 \mathrm{ml}$. of each was examined after 15 and 30 minutes incubation and the number of viable organisms present determined by the method of Miles and Mizra (1938). With the NCTC strain, the mean count at 15 minutes was reduced from $10 \times 10^{6}$ to 15.5 to $10^{4}$, and aft 30 minutes the effect was lethal. Two clinical isolates were also tested. They were less sensitive but none was recovered after 30 minutes (Table II). Similar tests were carried out with Escherichia coli and Staphylococcus aureus with no loss of viability after 60 minutes. 
TABLE II Number of viable organisms present after exposure to Nonyl-P

\begin{tabular}{|c|c|c|c|c|c|c|}
\hline \multirow{2}{*}{$\begin{array}{l}\text { Strain of } \\
\text { N. gonorrhoeae } \\
\text { NCTC } 3375\end{array}$} & \multirow{2}{*}{$\begin{array}{l}\begin{array}{l}\text { Exposure } \\
\text { time } \\
\text { (min.) }\end{array} \\
0\end{array}$} & \multicolumn{4}{|c|}{ Viable count (organisms per $\mathrm{cm}^{3}$ ) } & Mean count \\
\hline & & $10 \times 10^{6}$ & $7.5 \times 10^{6}$ & $11 \times 10^{6}$ & $12 \times 10^{6}$ & $10 \times 10^{6}$ \\
\hline & 15 & $15 \times 10^{4}$ & $13.5 \times 10^{4}$ & $16 \times 10^{4}$ & $17 \times 10^{4}$ & $15.5 \times 10^{4}$ \\
\hline & 30 & 0 & 0 & 0 & 0 & 0 \\
\hline & 30 & 0 & 0 & 0 & 0 & 0 \\
\hline \multirow[t]{2}{*}{ Clinical isolate (2) } & 0 & $9 \times 10^{8}$ & $13 \times 10^{8}$ & $\times 10^{8}$ & $12 \times 10^{8}$ & $11.5 \times 10^{8}$ \\
\hline & 10 & $6 \times 10^{8}$ & $5 \times 10^{8}$ & $3.5 \times 10^{8}$ & $4.5 \times 10^{8}$ & $4.7 \times 10^{8}$ \\
\hline
\end{tabular}

\section{Discussion}

Singh and others (1972), using a time-exposure test, obtained a growth of $N$. gonorrhoeae after exposure to 20 per cent. solution Nonyl-P in saline for $10 \mathrm{~min}$. No growth, however, was obtained by a platedilution method with a concentration of 10 per cent.

In the present study, using the plate-dilution method, the critical dilution for inhibition lay between 0.2 and 0.4 per cent. No viable organisms were recovered after exposure to 0.6 per cent. Nonyl-P for $30 \mathrm{~min}$. This concentration is less than an estimated level produced by a $1.75 \mathrm{ml}$. pessary of 5 per cent. Nonyl-P, after allowing for dilution by vaginal fluid and ejaculate.

It is likely that the active constituent would remain in the vagina for some hours. Shannon, Tinkler, and Hedges (1968) reported the persistence of amphotericin B 24 hours after application.

Nonyl-P has been used for many years as a contraceptive agent. Our findings suggest that it could be used to assist control of the spread of gonorrhoea in a permissive society. It might lessen the risk of reinfection among consorts who cannot be treated simultaneously. If used in the trial of a new drug for the treatment of gonorrhoea it might help separate the cases of true treatment failure from re-infections.

\section{Summary}

Nonyl-P has been used as a vaginal contraceptive agent for many years. Using a plate-dilution method, there was no growth of gonococci in the presence of 0.6 per cent. Nonyl-P. Further tests showed that this concentration was lethal to the organism after $30 \mathrm{~min}$ utes exposure. The use of such a compound might help to control the spread of gonorrhoea.
We should like to thank Dr. J. B. Williams, Director of Pathological Services, for his advice and encouragement, and Messrs. W. J. Rendell Ltd., for a supply of Nonyl-P.

\section{References}

ARnold, R. C., and Cutler, J. C. (1970) Publ. Hlth Rep. (Wash.), 85, 1062

Behne, D., Clark, F., Jennings, M., Pallais, V., Olson, H., Wolf, L., and TYLER, E. T. (1956) Obstet. and Gynec., 64, 152

Catterall, R. D. (1970) Brit. F. Hosp. Med., 3, 55

GuTHE, T. (1972) Hlth Visitor, 45, 39

Hotchkiss, R. S. (1945) 'Fertility in Men', p. 144. Heinemann, London

KING, A. (1970) Brit. med. F., 1, 451

Miles, A. A., and MisRA, S. S. (1938) f. Hyg. (Lond.), 38, 372

RovinSKY, J. J. (1964) Obstet. and Gynec., 23, 125

Shannon, R., TinkleR, A. E., and Hedges, A. J. (1968) Brit. F. vener. Dis., 44, 235

Singh, B., CUTleR, J. C., and Utidjian, H. M. D. (1972) Ibid., 48, 57

WEBSTER, B. (1970) Ibid., 46, 406

Une note sur la susceptibilité de $\boldsymbol{N}$. gonorrhoeae au produit contraceptif Nonyl-P (nonyl phénoxyl polyéthoxyl éthanol)

\section{SOMMAIRE}

Le Nonyl-P est utilisé comme produit contraceptif vaginal depuis de nombreuses années. En utilisant la méthode des dilutions sur plaque, les gonocoques ne poussèrent pas en présence de 0,6 pour cent de Nonyl-P. Des épreuves supplémentaires montrèrent que le germe était tué à cette concentration après un contact de 30 minutes. L'emploi d'un tel composé peut se montrer utile dans la lutte contre le développement de la gonococcie. 